\title{
Palm Polysaccharides in the Diet of Broilers Challenged Against Escherichia coli: A Preliminary Study
}

\author{
Sundu $\mathrm{B}^{1}$, Bahry $\mathrm{S}^{2}$, Dien $\mathrm{R}^{1}$ \\ ${ }^{1)}$ Department of Animal Husbandry, University of Tadulako, Palu \\ ${ }^{2)}$ Department of Chemistry, Faculty of Science, University of Tadulako, Jl. Soekarno Hatta km 9, \\ Palu 94148, Central Sulawesi, Indonesia \\ b_sundu@yahoo.com
}

\begin{abstract}
The use of palm polysaccharides in broiler diet as a feed additive has recently been reported with promising results. A study was conducted to determine the use of palm polysaccharides in broiler diets when the birds were challenged with E. coli. A total of 32 unsexed broilers, with the similar body weight (1400-1480 g) was selected and used in this study as experimental birds. The birds were kept in the individually metabolism cages for 2 weeks. Feed and and water were available at all times. The diet was formulated to meet the nutrients need for grower chickens. Four different types of feed additives (Control, palm kernel polysaccharides, copra polysaccharides, antibiotic avilamycin), with and without $E$. coli challenge were used in this study. The birds were challenged with E.coli for three consecutive days (days 8 to 10), after a week of adaptation period. A completely randomised factorial design was used with the first factor is feed additive (Control, palm kernel polysaccharides, copra polysaccharides, antibiotic avilamycin), the second factor is two types of E. coli challenge (with or without $E$. coli challenge) and four replications. Differences among treatmens found were further tested with Tukey test. The results indicated that the supplementation of feed aditives (palm kernel polysaccharides, copra polysaccharides and avilamycine) improved body weight gain, FCR and excreta dry matter. The birds challenged with E. coli produced lower body weight gain and feed intake. Interaction between type of feed additives and $E$. coli challenge was found in body weight gain, feed intake, FCR and excreta dry matter. In conclusion, feed additives improved the quality of the diet and E. coli challenge had detrimental effect on bird performance. There was an interaction between type of feed additives and $E$. coli challenge on body weight gain, feed intake, FCR and excreta dry matter.
\end{abstract}

Key Words: Palm Polysaccharides, E. coli, Broilers

\section{INTRODUCTION}

Indonesia has been the largest palm oil producer and the second largest coconut producer in the world. This may indicate that large amount of byproducts was produced from oil extraction of these two agricultural products. Palm kernel meal and copra meal are byproducts of these palm trees that intensively studied in many palm oil and coconut producing countries. However, studies in this area were mainly related to the effort of improving their quality as feed ingredients.

Of the fractions of nutrients present in palm kernel meal and copra meal, carbohydrates was the main component (Knudsen 1997). Palm carbohydrates have been reported to mainly in the form of non-starch polysaccharides, being $81 \%$ in palm kernel meal and $42.2 \%$ in copra meal (Knudsen 1997). Of the total non-starch polysaccharides in palm kernel meal, $70 \%$ was mannose-based polysaccharides (linear mannan), 12\% cellulose and 6\% xylane (Duesterhoft et al. 1991), while in copra meal was. 26\% mannan, $61 \%$ galactomannan and $13 \%$ cellulose (Balasubramaniam 1976). This indicates that polysachharides in these two agricultural byproducts were mannose based or mannan.

Due to the fact yeast mannan has been succesfully proven to be prebiotic over the last three decades (Lyons 2002), mannose based polysaccharides present in these byproducts may also have the same properties as found in yeast mannan. Early study of Fernandez et 
al. (2000) indicated that the population of pathogenic bacteria deacreased in the digestive tract of broilers when the birds were fed palm kernel meal. Sundu \& Damry (2008) reported that the use of mannose based polysaccharides from copra meal in broiler diets increased body weight of birds. Accordingly, a study was conducted to determine the effect of polysaccharides from these two byproducts on broiler performance and moisture content of excreta.

\section{MATERIAL AND METHODS}

\section{Mannan extraction}

A method of Kusakabe \& Takashi (1988) was used to extract mannose based polysaccharides from copra meal and palm kernel meal. Sixteen litres of $20 \% \mathrm{NaOH}$ concentration was added to $2 \mathrm{~kg}$ of palm kernel meal or copra meal in a bucket. The mixture was occasionally stirred for 24 hours at room temperature. The slurry was then filtered through a cloth bag. The filtrate was neutralized with $12 \mathrm{~N} \mathrm{H}_{2} \mathrm{SO}_{4}$ until the pH solution is about 5.5. Resultants precipitate (mannose based polysaccharides) collected by centrifugation, was dialysed against tap water to remove salts. The leftover residue was as a copra mannan as it was analysed by Kusakabe \& Takashi (1988).

\section{Birds and feed}

A feeding trial was conducted in the poultry house at the University of Tadulako Palu, Indonesia. A total of 32 unsexed Cobb chickens was used as experimental animals. They were placed in the individually metabolism cages for two weeks. The birds were allowed to consume basal feed (Table 1) during the first week of adaptation period. After adaptation period, the birds were offered experimental diets (Table 2). Water was provided ad-libitum throughout the trial. The cages were routinely cleaned.

Table 1. Composition of the experimental control basal diet (\%)

\begin{tabular}{lc}
\hline \hline Ingredients & Grower diet \\
\hline Full fat soybean meal & 18.97 \\
Corn & 62.10 \\
Fish meal & 11.00 \\
Rice bran & 3.90 \\
Palm oil & 1.00 \\
Dicalcium phosphate & 1.20 \\
Salt & 0.20 \\
Methionine & 0.15 \\
Lysine & 0.11 \\
Vitamine and mineral mixture & 0.20 \\
Calculated nutrient & \\
Crude protein & 21.00 \\
ME (kcal/kg) & 3187.00 \\
Crude fibre & 3.60 \\
Lysine & 1.00 \\
Methionine & 0.40 \\
Calcium & 1.00 \\
Phosporous & 0.70 \\
\hline
\end{tabular}


Table 2. Experimental diets

\begin{tabular}{lcc}
\hline \hline Type of additive & E. coli challenge & Replications \\
\hline Control & - & 4 \\
& + & 4 \\
Control + 0.05\% palm kernel polysaccharides (PKP) & - & 4 \\
& + & 4 \\
Control + 0.05\% copra polysaccharides (CP) & - & 4 \\
Control + 2 ppm avilamycin & + & 4 \\
& - & 4 \\
\hline
\end{tabular}

\section{Challenge protocol and parameters}

After adaptation period, the birds were challenged against $E$. coli with the concentration of $1.5 \times 10^{8} \mathrm{CFU} / \mathrm{ml}$ on days 8,10 and 12 . This pathogenic bacteria was kindly provided by Health Laboratory, Undata Hospital, Palu Central Sulawesi. $5 \mathrm{ml}$ of E.coli containing fluid was offered in drinking water. During a week of challenge period, feed intake and body weight were recorded. Total excreta from each broiler in the metabolism cages were collected for three consecutive days (days 13 to 15). The excreta was individually weighed after discarding any foreign materials, such as feather and spilled feed particles. The excreta was oven dried at at $65^{\circ} \mathrm{C}$ for 24 hours (AOAC 1990).

\section{Statistical analysis}

This study used a randomized complete design with seven treatment diets and four replicate cages of one bird each metabolism cage. Data were analysed by analysis of variance and differences among treatments found in the analysis of variance were further tested for significance by Tukey Test (Steel \& Torrie 1980).

\section{RESULTS AND DISCUSSION}

\section{Results}

The data on the effect of type of feed additives on bird performance, effect of $E$. coli challenge on bird performance and the effect of interaction between type of feed additives and E. coli challenge on bird performance were shown in Table 3, 4 and 5, respectively. The effects of type of feed additives on body weight gain, FCR and excreta dry matter was significantly affected. The effect of $E$. coli challenge significantly affected body weight gain and feed intake. There was an interaction between type of feed additives and E. coli challenge on bird performance.

Table 3. Effect of type of additive on body weight gain, feed intake, FCR and excreta dry matter

\begin{tabular}{lcccc}
\hline \hline \multirow{2}{*}{ Treatments } & \multicolumn{4}{c}{ Parameters } \\
\cline { 2 - 5 } & BWG $(\mathrm{g})$ & Feed Intake $(\mathrm{g})$ & FCR & Excreta DM $(\%)$ \\
\hline Control & $407^{\mathrm{b}}$ & $773^{\mathrm{a}}$ & $1.92^{\mathrm{a}}$ & $18.9^{\mathrm{b}}$ \\
Control + PKP & $472^{\mathrm{a}}$ & $810^{\mathrm{a}}$ & $1.72^{\mathrm{b}}$ & $23.7^{\mathrm{a}}$ \\
Control + CP & $473^{\mathrm{a}}$ & $814^{\mathrm{a}}$ & $1.72^{\mathrm{b}}$ & $24.5^{\mathrm{a}}$ \\
Control + Avilamycin & $474^{\mathrm{a}}$ & $800^{\mathrm{a}}$ & $1.70^{\mathrm{b}}$ & $24.8^{\mathrm{a}}$ \\
\hline
\end{tabular}

Palm kernel polysaccharides (PKP); Control + copra polysaccharides (CP)

Values followed by different superscript significantly different at $\mathrm{P}<0.05$ 
Table 4. Effect of E.coli challenge on body weight gain, feed intake, FCR and excreta dry matter

\begin{tabular}{lrc}
\hline \hline \multirow{2}{*}{ Parameters } & \multicolumn{2}{c}{ Treatments } \\
\cline { 2 - 3 } & E. coli & + E. coli \\
\hline Body weight gain $(\mathrm{g})$ & $476.00^{\mathrm{a}}$ & $436.00^{\mathrm{b}}$ \\
Feed Intake $(\mathrm{g})$ & $824.00^{\mathrm{a}}$ & $774.00^{\mathrm{b}}$ \\
Feed conversion ratio & $1.73^{\mathrm{a}}$ & $1.80^{\mathrm{a}}$ \\
Excreta dry matter $(\%)$ & $24.20^{\mathrm{a}}$ & $21.70^{\mathrm{a}}$ \\
\hline
\end{tabular}

Table 5.Effects of interaction between type of diet and bacteri challenge on body weight gain (BWG), feed intake (FI), FCR and excreta dry matter

\begin{tabular}{lccccc}
\hline \multicolumn{1}{c}{ Treatments } & \multicolumn{5}{c}{ Variables } \\
\hline Type of additive & E. coli & BWG $(\mathrm{g})$ & FI (g) & FCR & $\begin{array}{c}\text { Excreta DM } \\
(\%)\end{array}$ \\
\hline Control & - & $479^{\mathrm{a}}$ & $866^{\mathrm{a}}$ & $1.82^{\mathrm{b}}$ & $22.9^{\mathrm{a}}$ \\
& + & $334^{\mathrm{b}}$ & $679^{\mathrm{b}}$ & $2.03^{\mathrm{a}}$ & $14.9^{\mathrm{b}}$ \\
Control + PKP & - & $474^{\mathrm{a}}$ & $812^{\mathrm{a}}$ & $1.71^{\mathrm{b}}$ & $23.8^{\mathrm{a}}$ \\
& + & $469^{\mathrm{a}}$ & $807^{\mathrm{a}}$ & $1.72^{\mathrm{b}}$ & $23.7^{\mathrm{a}}$ \\
Control + CP & - & $474^{\mathrm{a}}$ & $813^{\mathrm{a}}$ & $1.71^{\mathrm{b}}$ & $24.9^{\mathrm{a}}$ \\
& + & $471^{\mathrm{a}}$ & $815^{\mathrm{a}}$ & $1.73^{\mathrm{b}}$ & $24.0^{\mathrm{a}}$ \\
Control + Avilamycin & - & $477^{\mathrm{a}}$ & $804^{\mathrm{a}}$ & $1.69^{\mathrm{b}}$ & $25.0^{\mathrm{a}}$ \\
& + & $470^{\mathrm{a}}$ & $797^{\mathrm{a}}$ & $1.70^{\mathrm{b}}$ & $24.5^{\mathrm{a}}$ \\
\hline
\end{tabular}

\section{Discussion}

The use of prebiotic, either in the form of palm kernel polysaccharides or copra polysaccharides in broiler diets could increase body weight gain of broilers (Sundu et al. 2006; Sundu et al. 2009). These palm polysaccharides produced the same body weight gain as found in the birds fed antibiotic avilamycin. This indicates that the palm polysaccharides could replace avilamycin in the broiler diets. The improvement of body weight gain due to either palm polysaccharides and antibiotic supplementation might be partly due to the increase in the health status of the digestive tract of birds. Our current finding indicated that when the birds were challenged against pathogenic bacteria $(E$. Coli), body weight gain of birds decreased by $40 \mathrm{~g}$. This preliminary study might bring hope for the controversy of the use of antibiotic in broiler diets.

Feed conversion ratio (FCR) was significantly improved when the diets were supplemented with either palm polysaccharides or antibiotic. Since there was no significant effect of the type feed additive on feed intake, it can be speculated here that the feed additives used in this current study may be effective in improving the quality of feed. However, the mechanism of improving feed quality is hard to rasionalize. It is possibly through the increase in feed digestibility or feed absorption as a results of the increased health status of absorption site in the digestive tract. Feed intake of birds challenged against E. coli dropped from $824 \mathrm{~g}$ to $774 \mathrm{~g}$. The decrease in feed intake is probably because of impaired digestibility and absorption. However, a study in the area of histology of the digestive tract and digestibility is needed to prove this speculation.

Wetter excreta was found in the birds fed the control diet. The supplementation of the control diet with palm carbohydrate or antibiotic avilamycin increased the dry matter of the excreta. Of eight experimental units in the birds fed control diet, 2 birds were suffering 
from diarrhea and the birds were in the E. coli - challenged treatment. The problem of wet excreta is becoming more crucial as this could not only affect the health of the birds but also rise the environmental issue.

The interaction between type of additive and E. coli challenge was found in all parameters investigated. However, the pattern of interaction was relatively the same. The detrimental effect of the challenge of the birds against $E$. coli was only found when the birds fed the control diet. Supplementation of the control diet with palm polysaccharides or antibiotic could eliminate the negative effect of the pathogenic bacteria on body weight gain, feed intake, FCR and excreta dry matter. Since this is only a preliminary study with small number of birds used and few parameters investigated, it is too early to state that these two palm polysaccharides have the same efficacy as found in antibiotic avilamycin. A longer study with large number of birds and more parameters is needed to support this finding. However, this preliminary study produced a promising result.

\section{CONCLUSION}

Supplementation of the diet with palm polysaccharides or antibiotic avilamycin improved body weight gain, feed conversion ratio and dry matter of excreta. The interaction between type of feed additive and $E$. coli challenge was found in body weight gain, feed intake, feed conversion ratio and dry matter of excreta.

\section{REFERENCES}

Balasubramaniam K. 1976. Polysaccharides of the kernel of maturing and mature coconuts. J Food Sci. 41:1370-1373.

Duesterhoft EM, Voragen GJ, Engels FM. (1991). Non-starch polysaccharide from sunflower (Helianthus annuus) meal and palm kernel (Elaeis guineensis) meal preparation of cell wall material and extraction of polysaccharide fractions. J Sci Food Agric. 55:411-422.

Daud MJ, Jarvis MC. 1992 Mannan of oil palm kernel. Phytochemistry. 31:463-464.

Fernandez F, Hinton M, Van Gils B. 2002. Dietary mannan oligosaccharides and their effect on chicken caecal miclofora in relation to Salmonella enteriditis colonization. Avian Pathol. 31:49-58.

Knudsen KEB. (1997). Carbohydrate and liginin contents of plant materials used in animal feeding. Anim Feed Sci Technol. 67:319-338.

Kusakabe I, Takashi R. 1988. Enzymatic preparation beta 1-4 mannooligosaccharides and beta 1-4 gluco-mannooligosaccharides. Methods Enzymol. 160:518-523.

Lyons TP. 2002. Navigating from niche market to mainstream. A feed industry kakumei. Proceedings of Alltech's 16th Annual Asia Pacific Lecture Tour. Beijing, China. Nottingham (UK): Nottingham University Press. p. 1-16.

Steel RGD, Torrie JA. 1980. Principles and procedures of statistics. New York (USA): McGraw Hill.

Sundu B, Kumar A, Dingle J. (2006). Palm kernel meal in broiler diets: its effect on chicken performance and health. World's Poult Sci J. 62:316-325.

Sundu B, Kumar A, Dingle J. (2009). Feeding value of copra meal for broilers. World's Poult Sci J. 65:481-491.

Sundu B, Damry HB. (2008) Ekstrak beta mannan dari kelapa sebagai pengganti antibiotik untuk unggas. Laporan penelitian Fundamental, Untad. Palu (Indonesia): Universitas Tadulako. 